\title{
MODEL PEMBELAJARAN KOOPERATIF JIGSAW UNTUK MENINGKATKAN HASIL BELAJAR (TENSES) MAHASISWA DKV UNINDRA
}

\author{
Fitria Iswari $^{1}$, Puri Kurniasih ${ }^{2}$ \\ Program Studi Desain Komunikasi Visual, Universitas Indraprasta PGRI ${ }^{12}$ \\ Email: fitriaiswari@gmail.com ${ }^{1}$
}

\begin{abstract}
Abstrak
Dalam keberhasilan proses belajar salah satunya dapat dilihat melalui hasil belajar yang diperoleh oleh peserta didik. Bahasa Inggris 1 menjadi mata kuliah yang wajib diambil oleh mahasiswa semester 1 prodi DKV Unindra. Sesuai kurikulum mahasiswa dituntut untuk mampu menguasai tense. Dalam keadaanya dosen menggunakan metode pembelajaran konvensional berupa ceramah, dan hasil belajar siswa sangat rendah. Penelitian ini bertujuan untuk menggambarkan hasil belajar siswa dengan metode pembelajaran kooperatif Jigsaw. Penelitian ini berbentuk tindakan kelas dengan pendekatan deskripsi kualitatif. Pemerolehan data melalui test yang dilakukan sebelum dan sesudah tindakan kelas, dan observasi. Dari data yang di dapat sebesar $52,6 \%$ hasil belajar siswa meningkat untuuk kelas 3 eksperimen, dan $47,6 \%$ peningkatan hasil belajar yang didapat oleh kelas 4 eksperimen. Hal ini menunjukan bahwa model pembelajaran kooperatif Jigsaw mampu meningkatkan hasil belajar siswa.
\end{abstract}

Kata Kunci : Jigsaw, Tenses, Hasil Belajar.

\begin{abstract}
Students' learning outcomes is one of indicators to see the success of learning process. English 1 is a subject taken by 1st semester students of DKV study program of Indraprasta PGRI University. According to the Curriculum, students are required to be able to master tense. In the reality lecturer still uses the conventional learning model and students' learning outcomes is very low. This research is aimed to describe the learning outcomes of Jigsaw model. This study was conducted through action research with qualitative descriptive approach. The data collections are from the pretest, post test, and observation. Based on the data, there was $52.6 \%$ improvement learning outcomes of experiment class 3 and $47.6 \%$ improvement learning outcomes of experiment class 4. It shows that Jigsaw model can improve students' learning outcomes.
\end{abstract}

Key Words : Jigsaw, Tenses, learning Outcomes

\section{PENDAHULUAN}

Sudah tidak asing lagi bahwa bahasa inggris adalah bahasa yang digunakan hampir diseluruh dunia. Dalam proses pembelajaran Bahasa Inggris ada 4 kemampuan/ keterampilan yang harus dikuasai oleh peserta didik, yaitu 4 keterampilan yaitu membaca (reading), mendengarkan (listening), menulis (witing), berbicara (speaking). Dalam kurikulum Universitas Indraprasta PGRI Program Studi Desain Komunikasi Visual (DKV), mata kuliah Bahasa Inggris 1 terdapat di semester gasal dan sementara mata kuliah Bahasa Inggris Desain terdapat di semester genap. Keberhasilan suatu pembelajaran salah satunya ditandai dengan hasil belajar yang baik. Selain materi yang baik, pendidik yang menguasai materi, serta media pembelajaran yang menarik, model pembelajaran juga mempengaruhi dalam pencapaian keberhasilan belajar. Sejauh ini model pembelajaran yang digunakan oleh kebanyakan dosen adalah model konvensional teacher's center; dosen menerangkan lalu mahasiswa diberi ruang bertanya, namun model ini tidak efektif membuat mahasiswa menjadi aktif, sehingga dibutuhkan alternatif model pembelajaran lain.

Dari latar belakang masalah tersebut peneliti ingin menguji model pembelajaran 
Jigsaw, sebagai salah satu model pembelajaran yang kooperatif dan melibatkan mahasiswa lebih banyak. Apakah model pembelajaran ini mampu meningkatkan hasil belajar mahasiswa selama ini. Tujuan penelitian ini adalah untuk menemukan hasil penggunaan model pembelajaran kooperatif Jigsaw yang kemudian dibandingkan dengan metode pembelajaran konvensional yaitu berupa ceramah. Dari kedua metode tersebut metode pembelajaran manakah yang mampu meningkatkan hasil belajar siswa dengan baik.

Dengan demikian, penelitian ini akan menggunakan matode tindakan kelas atau action research dengan pengumpulan data melalui observasi, dokumentasi, mengumpulkan hasil tes sebelum dan sesudah penerapan model pembelajaran kooperatif Jigsaw, kemudian menganalisisnya secara deskriptif dengan komparatif, yaitu membandingkan model pembelajaran konvensional dengan kooperatif Jigsaw.

Peneliti memilih model pembelajaran kooperatif karena melihat hasil studi pembelajaran kooperatif mampu meningkatkan hasil belajar siswa seperti artikel yang menjelaskan bahwa penggunaan model pembelajaran model cooperative Jigsaw, diantaranya: Eksperimentasi Model Pembelajaran Kooperatif Tipe Jigsaw II dan Think Pair Share Ditinjau dari Kecerdasan Emosional Siswa SMP Se-Kota Kediri Tahun Pelajaran 2012/2013 [1], Meningkatkan pemahaman siswa pada konsep listrik melalui pembelajaran kooperatif tipe Jigsaw pada siswa kelas IX SMPN 43 Bandung [2], Pengaruh Penggunaan Pembelajaran Kooperatif Tipe Jigsaw dalam Pembelajaran Biologi di SMPN 2 Cimalaka[3], Penerapan Model Pembelajaran Kooperatif Jigsaw Untuk Meningkatkan Hasil Belajar Matematika
Tentang Denah Letak Benda Pada Siswa Kelas VI SDN 6 Besito [4], Model Pembelajaran kooperatif Jigsaw untuk Meningkatkan hasil Belajar Siswa Kelas IX-3 Materi Membaca Teks Report Pelajaran Bahasa Inggris SMP Negeri 2 Dewantara Aceh Utara [5], Using handhelds in a Jigsaw cooperative learning environment [6], Effect of Jigsaw II on literal and higher order EFL reading comprehension [7]. Hal ini menandakan bahwa penerapan model pembelajaran kooperatif Jigsaw memberikan dampak positif. Berdasarkan tinjauan pustaka tersebut, belum ada yang menerapka model pembelajaran kooperatif Jigsaw pada kelas Bahasa Inggris dengan materi tenses di perguruan tinggi, serta semua artikel tidak memberikan perbandingan antara model pembelajaran konvensional dengan model kooperatif Jigsaw.

Penelitian ini akan menunjukkan apakah model pembelajaran kooperatif Jigsaw akan meningkatkan hasil belajar khususnya Tenses pada mahasiswa DKV Unindra dibandingkan dengan model pembelajaran konvensional.

\section{METODE}

Penelitian ini merupakan penelitian tindakan kelas atau action research. Sugiyono [8] menyatakan bahwa penelitian eksperimen dapat diartikan sebagai metode penelitian yang digunakan untuk mencari pengaruh perlakuan tertentu terhadap yang lain dalam kondisi yang terkendalikan.

Penelitian ini di lakukan di Universitas Indrapasta PGRI Jakarta Program Studi Desain Komunikasi Visual (DKV), yang dilakukan pada Semester Gasal Pada bulan September dam Oktober. Subjek penelitian ialah mahasiswa DKV semester1 yang berjumlah 4 kelas/rombel masing- masing kelas terdiri dari 45 mahasiswa. Ke-4 kelas tersebut akan dibagi menjadi 2 kelas ekperimen dan 2 kelas control. Objek 
penelitian ialah hasil pembelajaran Tenses pada mata kuliah Bahasa Inggris 1.

Data yang didapat dalam penelitian ini melaui Observasi (pengamatan langsung, dokumentasi yang dapat menggambarkan perilaku peserta didik selama proses berlangsung, dan yang terakhir adalah hasil tes yang dilakukan di awal dan akhir penerapan model pembelajaran kooperatif Jigsaw yang mampu menggambarkan hasil dari penerapan model pembelajaran kooperatif Jigsaw. Teknik analisis data ialah teknik analisis dekskriptif, yang meliputi analisis deskripsi komparatif hal ini dilakukan dengan cara membandingkan hasil belajar pada siklus I dan II.

\section{HASIL DAN PEMBAHASAN}

Tenses, Jigsaw dan Action research

Dalam penguasaan keterampilan Berbahasa Inggris tidak terlepas dari peran Tenses. Tenses digunakan dalam setiap aspek keterampilan sebagai penanda waktu aktivitas tersebut berlangsung. Ali [9] mengungkapkan pengertian Tenses dapat diartikan sebagai suatu gambaran atau penjelasan kapan suatu peristiwa, kejadian, atau tindakan terjadi di dalam kalimat yang sesuai dengan keadaan antara: sekarang, lampau, atau akan datang. Dengan pengertian tersebut penguasaan Tenses menjadi sangat penting dalam pembelajaran Bahasa Inggris.

Sesuai modul untuk mahasiswa yang dibuat oleh LPB (Lembaga Pusat Bahasa) Universitas Indraprasta PGRI Jakarta, materi dalam Bahasa Inggris 1 meminta mahasiswa untuk mampu menguasai berbagai macam Tenses, diantaranya: (1) Simple present tense, (2) Simple past tense, (3) Present future, (4) Present continuous, dan (5) Present perfect.

Dalam hal ini peneliti sekaligus sebagai dosen mengamati untuk materi Tenses mahasiswa mendapatkan skor yang sangat rendah, rata- rata skor yang di dapat selalu di bawah 60. Aunurrahman [10] menyatakan bahwa hasil belajar adalah kemampuan yang diperoleh anak setelah melalui kegiatan belajar. Hal ini menujukan bahwa hasil belajar produk dari proses belajar itu sendiri.

Kebanyakan dosen masih menggunakan metode pembelajaran konvensional, yaitu dimana dosen sebagai pusat atau dikenal sebagai teacher's center menjelaskan kepada mahasiswa seluruh materi yang akan diajarkan, dan mahasiswa dilibatkan dalam sesi tanya jawab. Dalam kenyataanya mahasiswa cenderung bersikap pasif, jarang bertanya, dan tidak mampu menjawab pertanyaan yang diajukan oleh dosen.

Berbagai macam upaya yang dilakukan untuk mampu meningkatkan hasil belajar salah satunya model pembelajaran kooperatif. Model pembelajaran yang kooperatif dan melibatkan mahasiswa lebih banyak, khususnya di kelas Bahasa Inggris pada materi Tenses. Ghazi Ghaith [7] sukses membuktikan dalam penelitiannya bahwa metode cooperative jigsaw dapat membantu dalam meningkatkan kemampuan reading comprehension. Menurut Slavin [11] model pembelajaran kooperatif adalah model pembelajaran dimana para siswa bekerjasama dalam kelompok-kelompok kecil saling membantu satu sama lainnya dalam mempelajari materi pembelajaran. Sementara menurut C-Y Lai dan C-C Wu [6] mengikuti metode Jigsaw seperti masuk menjadi bagian-bagian dari puzzle, sehingga semuanya turut serta karena masing-masing memiliki peran yang penting dalam pembelajaran. Berdasarkan penjelasan di atas peneliti mengharapkan kelas yang jauh lebih hidup dan aktif karena masing-masing mahasiswa mengemban tanggungjawab masingmasing. Menurut Johnson \& Johnson (1994) dalam Trianto [12] untuk mencapai 
hasil maksimal, terdapat lima unsur penting dalam pembelajaran kooperatif, yaitu:

1. Saling ketergantungan yang positif antar siswa

2. Interaksi antar siswa yang semakin meningkat

3. Tanggungjawab individual

4. Keterampilan interpersonal dan kelompok kecil

5. Proses kelompok.

Model pembelajaran kooperatif Jigsaw merupakan salah satu dari model pembelajaran kooperatif. Menurut Rusman [13] dalam model pembelajaran Jigsaw ini siswa memiliki banyak kesempatan untuk mengemukanakan pendapat, dan mengelolah informasi yang didapat dan dapat meningkatkan keterampilan berkomunikasi, anggota kelompok bertanggung jawab atas keberhasilan kelompoknya dan ketuntasan bagian materi yang dipelajari, dan dapat menyampaikan kepada kelompoknya. Sejalan dengan Rusman, Melvin L. Silberman [14] menjelaskan bahwa Jigsaw learning merupakan sebuah teknik yang dipakai secara luas yang memiliki kesamaan dengan teknik "pertukaran dari kelompok ke kelompok" (group-to-group exchange) dengan suatu perbedaan penting. Berdasarkan penegertian para ahli maka pengertian model pembelajaran kooperatif Jigsaw adalah model pembelajaran yang melibatkan 4-6 siswa dalam kelompok ahli untuk saling bertukar pikiran dalam pembahasan yang sama dan kembali lagi ke kelompok asal untuk memberi informasi hasil diskusi dengan kelompok ahli.

Model pembelajaran tersebut kemudian akan diterapkan dengan cara action research atau tindakan kelas. Menurut Herawati Susilo [15] karakteristik penelitian tindakan kelas meliputi:

1. Masalah yang diteliti berupa masalah praktik pembelajaran sehari-hari di kelas yang dihadapi oleh guru atau calon guru termasuk bagaimana membelajarkan siswa dengan pendekatan kontekstual, bagaimana kecakapan hidup siswa dan bagaimana mengembangkan kompetensi siswa.

2. Diperlukan tindakan-tindakan tertentu untuk memecahkan masalah tersebut dalam rangka memperbaiki atau meningkatkan kualitas pembelajaran di kelas. Penjelasannya sebagai berikut bila terjadi permasalahan dalam proses pembelajaran di kelas maka perlu adanya tindakan misalnya penerapan model pembelajaran kooperatif guna meningkatkan kualitas pembelajaran.

3. Terdapat perbedaan keadaan sebelum dan sesudah dilakukan PTK, perbedaam keadaan ini akan terlihat disetiap siklusnya.

4. Guru sendiri yang berperan sebagai peneliti, baik secara perorangan maupun kelompok. Penelitian tindakan kelas merupakan upaya kolaboratif antara guru, peneliti dan siswa.

Adapun tahapan dalam penelitian ini, yaitu:

1. Persiapan, pada tahap ini peneliti menyiapkan materi untuk masingmasing kelas kontrol maupun kelas eksperimen.

2. Tindakan, dalam tahap ini peneliti melakukan pretest setelah peneliti memberi materi berupa metode ceramah ke-4 kelas, selanjutnya kaan diambil pretest sebelum melakukan metode kooperatif Jigsaw guna mengetahui kemampuan mahasiswa serta sebagai bahan acuan atas keberhasilan tindakan kelas yang dilkukan. Dalam tahap ini akan dibuat menjadi 2 siklus yaitu siklus I dan II. Selanjutnya ekperimen dilakukan selama 7 kali dalam 2 bulan. 2 kelas kontrol diajarkan dengan metode ceramah, sedangkan kelas ekperimen diajar dengan menggunakan metode kooperatif Jigsaw. Dalam 1 
kelas mahasiswa akad dibagi dalam sebuah kelompok yang terdiri dari 4-5 orang. Masing $\mathrm{m}$ - masing kelompok model kooperatif Jigsaw akan dberikan materi Tenses, yaitu:

a. Simple present tense

b. Simple past tense

c. Present future

d. Present continuous

e. Present perfect.

Masing- masing dari mereka yang berada pada kelompok asal akan diberikan materi yang berbeda. Kemudian mereka akan disebar dan dimasukan ke dalam kelompok ahli yang di dalamnya akan mendiskusikan materi yang sama, di dalam kelompok ahli dosen mengontrol setiap kelompok ahli agar materi yang di dapat sama.

3. Pengamatan, pada tahap ini peneliti melakukan pengamatan dengan menggunakan lembar observasi, dan melihat hasil tes yang di dapat.

4. Refleksi .pada tahapan ini setelah selesai berdiskusi dengan kelompok ahli maka para anggota kelompok kembali ke kelompok asal dan menjelaskan materi yang didapat dari kelompok ahli kepada kelompok asal. Dalam tahap ini peneliti melihat hasil data yang didapat.

\section{Model Pembelajaran Konvensional: Metode Ceramah}

Pada pembahasan ini menggambarkan kondisi dan hasil yang terjadi pada tahap awal Dosen masuk ke dalam kelas kontrol maupun kelas ekperimen. Dalam pertemuan pertama ini Dosen selaku peneliti menjelaskan menjelaskan materi yang akan dipelajari serta tujuan dari pembelajaran tersebut. Tahap ini berlangsung sebanyak 2 kali pertemuan yang masing - masing memiliki durasi 100 menit. Pada tahap ini dosen menjelaskan berbagai macam Tenses, yaitu: (1) Simple present tense, (2) Simple past tense, (3) Present future, (4) Present continuous, (5) Present perfect, dengan metode konvensional atau dikenal dengan ceramah, dalam hal ini dosen menjadi sumber utama atau disebut juga teachers center dimana sang dosen menjadi kunci dari proses pembelajaran.

Setelah selesai penyampaian materi dosen melakukan pretest sebagai acuan awal sebelum pelaksanaan model pembelajaran kooperatif Jigsaw. Dosen memberikan gambar yang dimana mereka diminta untuk menuliskan kalimat berdasarkan gambar dengan Tenses yang sesuai.

Tabel 1. Hasil Skor Mahasiswa Pada Tahan Awal

\begin{tabular}{lcc}
\hline No & Kelas & Nilai Rerata \\
\hline 1. & 1 Kontrol & 15,9 \\
2. & 2 kontrol & 18,5 \\
3. & 3 Eksperimen & 17,6 \\
4. & 4 Eksperimen & 19,0 \\
\hline
\end{tabular}

Hasil yang di dapat dari 4 kelas masingmasing 2 kelas kontrol dan 2 kelas eksperimen menunjukan kelas yang paling rendah ialah kelas kontrol ke-1 dengan rerata 15,9 , selanjutnya kelas yang paling tinggi ialah kelas eksperimen 3 eksperimen yaitu 19,0. Berdasarkan dari hasil data yang didapat pada siklus 1 ditemukan beberapa mahasiswa yang mendapatkan nilai rendah bahkan 0 yang artinya dari jawaban tersebut tidak ada jawaban yang benar satupun. Dari ke-4 kelas tersebut seluruhnya masih dibawah rata- rata. Sedangkan batas nilai c mahasiswa membutuhkan 56 poin.

Sementara dari hasil pengamatan selama kegiatan berlangsung hanya ada 3 penanya dari ke-4 kelas tersebut, dan apabila dosen memberikan pertanyan kepada mahasiswa dengan maksud meyakinkan bahwa materi yang disampaikan mampu dipahami baik oleh mahasiswa dan beberapa mahasiswa menjawab salah dan bankan cenderung diam tidak menjawab pertanyaan. Dalam kondisi dimana dosen memberikan ceramah terlihat mahasiswa merasa bosan, 
dan sebagian dari mereka saling mengobrol di tengan proses pembelajaran. Berdasarkan hasil dari wawancara yang dilakukan kepada mahasiswa, ditemukan jawaban yaitu mahasiswa merasa bosen apabila mendengar penjelasaan dosen ditambah tuang kelas yang kurang kondusif. Melihat kondisi kelas yang terdiri dari 42-45 mahasiswa dalam 1 kelas. Maka pada tahap ini menggambarkan metode pembelajaran yang konvensional dimana dosen menjadi center dalam proses pembelajaran belum mampu meningkatkan hasil belajar siswa dibuktikan dengan skor yang di dapat sangat rendah.

\section{Deskripsi Siklus 1}

Dalam siklus ini dimulai penerapan model pembelajaran kooperatif Jigsaw. Dalam silus 1 dibutuhkan waktu $2 \mathrm{x}$ pertemuan.Pada tahap ini peneliti melakukan hal - hal, yaitu:

1. Dosen menyiapkan materi, serta lembar observasi.

2. Dosen membagi dalam kelompok yang terdiri dari 4-5 mahasiswa sebagai kelompok asal, kemudian membagi materi untuk didiskusikan pada kelompok ahli

3. Mahasiswa berdiskusi dengan kelompok ahli. Setelah selesai berdiskusi para anggota kelompok kembali ke kelompok asal dan menyampaikan apa yang mereka tau.

4. Dosen memonitoring kelompok asal.

5. Dosen melakukan test kepada masingmasing anggota

Setelah melakukan siklus pertama maka hasil yang di dapat adalah sebagai berikut:

Tabel 2. Hasil Skor Mahasiswa Pada Siklus I

\begin{tabular}{lcc}
\hline No & Kelas & Nilai Rerata \\
\hline 1. & 1 Kontrol & 30,9 \\
2. & 2 kontrol & 31,5 \\
3. & 3 Eksperimen & 31,3 \\
4. & 4 Eksperimen & 31,7 \\
\hline
\end{tabular}

Pada siklus 1 terjadi perubahan pada hasil belajar siswa. Terlihat skor yang diperoleh pada tahap ini meningkat jika dibandingkan dengan skor awal, namun belum terlalu signifikan. Dari hasil wawancara mahasiswa masih merasa canggung karena mereka belum saling mengenal terlalu dekat karena mereka adalah mahasiswa baru dalam kelas baru. Dalam hal ini peneliti melakukan perbaikan tindakan yang akan dilakukan pada penerapan model pembelajaran model Jigsaw siklus II.

\section{Deskripsi Siklus II}

Dalam siklus II tahap yang dilakukan hampir sama pada siklus I, namun peneliti melakukan beberapa perbaikan, pada siklus ini dibutuhkan waktu 3 x pertemuan, yang memiliki tahap sebagai berikut:

1. Dosen menyiapkan materi dan lembar observasi.

2. Dosen membagi mahasiswa dalam kelompok yang tediri dari 4-5 mahasiswa sebagai kelompok asal, kemudian membagikan materi untuk diskusikan pada kelompok ahli. Dalam prosesnya dosen melakukan pendampingan pada kelompok ahli, sebelum kembali ke kelompok asal dosen memberikan beberapa pertanyaan untuk memastikan pemahaman pada anggota kelompok ahli

3. Mahasiswa kembali ke kelompok awal untuk memberikan informasi yang didiskusikan pada kelompok ahli

4. Pada tahap akhir dosen memberikan post test sebagai soal uts. Yang dimana mahasiswa akan membuat kalimat berdasarkan Tenses yang sudah diminta.

Tabel 3. Hasil Skor Mahasiswa Pada Siklus II

\begin{tabular}{lcc}
\hline No & Kelas & Nilai Rerata \\
\hline 1. & 1 Kontrol & 31,6 \\
2. & 2 kontrol & 32,2 \\
3. & 3 Eksperimen & 60,6 \\
4. & 4 Eksperimen & 67,1 \\
\hline
\end{tabular}


Tabel 3 diatas menggambarkan perbedaan antara kelas kontrol dan kelas eksperimen. Tabel tersebut menggambarkan kelas eksperimen memperoleh hasil belajar yang lebih baik dibandingkan kedua kelas kontrol tersebut.

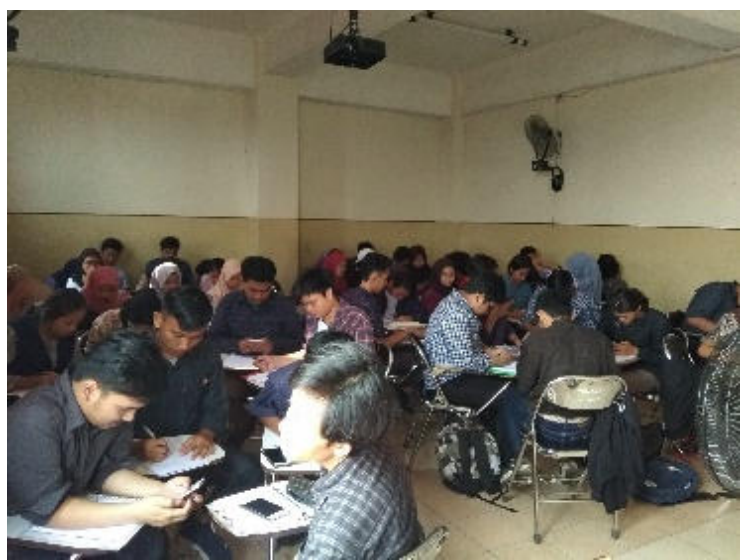

Gambar 1. Model Pembelajaran Kooperatif Jigsaw

Pada gambar 1 terlihat mahasiswa membentuk kelompok ahli untuk mendiskusikan materi Tenses.

\section{Hasil Belajar Siswa}

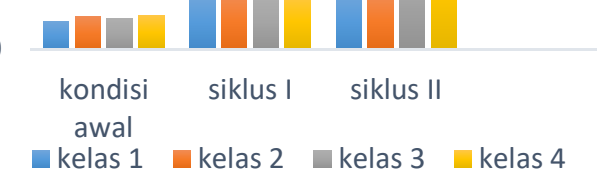

Gambar 2. Hasil Belajar siswa

Dari diagram di atas terlihat peningkatan hasil belajar siswa dalam mempelajari Tenses meningkat melalui model pembelajaran kooperatif Jigsaw. Untuk kelas eksperimen yaitu kelas 3 dan 4 mengalami peningkatan hasil belajar yang sangat signifikan pada siklus II. Peningkatan dari siklus I ke siklus II pada kelas eksperimen sebesar $52,6 \%$ pada kelas 3 eksperimen, dan $47,6 \%$ pada kelas 4 eksperimen. Hal ini menunjukan bahwa penerapan model belajar kooperatif Jigsaw mampu meningkatkan hasil belajar mahasiswa DKV terutama untuk materi Tenses.

\section{SIMPULAN}

Berdasarkan temuan yang diperoleh, maka dalam penelitian ini dapat ditarik kesimpulan, yaitu:

1. Model pembelajaran kooperatif Jigsaw mampu meningkatkan hasil belajar mahasiswa DKV Universitas Indrapasta PGRI, hal ini ditandai dengan peningkatan hasil belajar sebesar $52,6 \%$.

2. Model pembelajaran kooperatif Jigsaw jauh lebih efektif dibandingkan metode konvensional berupa ceramah.

3. Pendidik wajib memberikan pendampingan untuk kelompok asal maupun kelompok ahli guna membimbing peserta didik di dalam diskusi agar materi tersampaikan dengan baik.

\section{DAFTAR PUSTAKA}

[1] D. G. Andriani, T. A. Kusmayadi, and M. Mardiyana, "Eksperimentasi Model Pembelajaran Kooperatif Tipe Jigsaw II dan Think Pair Share Ditinjau dari Kecerdasan Emosional Siswa SMP Se-Kota Kediri Tahun Pelajaran 2012/2013," J. Pembelajaran Mat., vol. 1, no. 7, 2013.

[2] Y. Nurhaeni, "Meningkatkan pemahaman siswa pada konsep listrik melalui pembelajaran kooperatif tipe jigsaw pada siswa kelas IX SMPN 43 Bandung," J. Penelit. Pendidik., vol. 12, no. 1, pp. 77-89, 2011.

[3] Y. Sulastri and D. Rochintaniawati, "Pengaruh Penggunaan Pembelajaran Kooperatif Tipe Jigsaw dalam Pembelajaran Biologi di SMPN 2 Cimalaka," J. pengajaran MIPA, vol. 13, no. 1, pp. 15-22, 2009.

[4] Rokhis, "Penerapan Model Pembelajaran Kooperatif Jigsaw 
Untuk Meningkatkan Hasil Belajar Matematika Tentang Denah Letak Benda Pada Siswa Kelas VI SDN 6 Besito," Inopendas J. Ilm. Kependidikan, vol. 2, no. 1, pp. 18-29, 2019.

[5] V. Rohaza, "Model Pembelajaran kooperatif Jigsaw Untuk Meningkatkan hasil Belajar Siswa Kelas IX-3 materi Membaca Teks Report Pelajaran Bahasa Inggris SMP Negeri 2 Dewantara Aceh Utara," J. Media Inov. Edukasi, vol. 04, no. 13, pp. 213-219, 2018.

[6] C. Lai and C. Wu, "Using handhelds in a Jigsaw cooperative learning environment," J. Comput. Assist. Learn., vol. 22, no. 4, pp. 284-297, 2006.

[7] G. Ghaith and M. A. El-Malak, "Effect of Jigsaw II on literal and higher order EFL reading comprehension," Educ. Res. Eval., vol. 10, no. 2, pp. 105-115, 2004.

[8] Sugiyono, Metode Penelitian Kuantitatif Kualitatif dan $R \& D$. Bandung: Alfabeta, 2014.

[9] A. F. R. S. P. Ali, English Grammar Complite Edition. Yogyakarta: Pustaka Widyatama, 2010.

[10]Aunurrahman, Belajar dan Pembelajaran. Bandung: Alfabeta, 2010.

[11]R. E. Slavin, Cooperative Learning: Teori, Riset dan Praktik. Bandung: Nusa Media, 2011.

[12]Trianto, Medisain Model Pembelajaran Inofatif- Progresif: Konsep, Landasan dan Implementasinya pada Kurikulum Tingkat Satuan Pendidikan (KTPS). Jakarta: Kencana, 2010.

[13]Rusman, Manajemen Kurikulum Seri Manajmen Sekolah Bermutu. Bandung: UPI Press, 2008.

[14]M. L. Silberman, Active Learning 101 Strategi Pembelajaran Aktif. Yogyakarta: Pustaka Insan Madani,
2007.

[15]H. Susilo and Dkk, Penelitian Tindakan Kelas. Malang: Bayumedia, 2008. 